\title{
KőOLAJ-VÍZ EMULZIÓK REOLÓGIAI VIZSGÁLATA
}

\section{RHEOLOGICAL INVESTIGATION OF CRUDE OIL - WATER EMULSIONS}

\author{
Elekes Andrea ${ }^{1}$, Nagy Roland $^{2}$, Bartha László ${ }^{3}$, Vágó Árpád ${ }^{4}$ \\ 1 Pannon Egyetem, Mérnöki Kar, MOL Ásványolaj- és Széntechnológiai Intézeti \\ Tanszék, Magyarország, 8200 Veszprém, Egyetem utca 10. Telefon: +36-88-624- \\ 412,e-mail: elekesa@almos.uni-pannon.hu \\ 2 Pannon Egyetem, Mérnöki Kar, MOL Ásványolaj- és Széntechnológiai Intézeti \\ Tanszék, Magyarország, 8200 Veszprém, Egyetem utca 10. Telefon.: +36-88-624- \\ 412,e-mail:nroland@almos.uni-pannon.hu \\ 3 Pannon Egyetem, Mérnöki Kar, Vegyipari Müveleti Intézeti Tanszék, Magyaror- \\ szág, 8200 Veszprém, Egyetem utca 10. Telefon: +36-88-624-305, e-mail: \\ bartha@almos.uni-pannon.hu \\ ${ }^{4}$ MOL Nyrt., Csoportszintü Kutatás és Üzletfejlesztés, Magyarország, 1117 Buda- \\ pest, Októberhuszonharmadika u.18.e-mail:avago@mol.hu
}

\begin{abstract}
In the course of polymer-surfactant type enhanced oil recovery (EOR) are mixed the surfactant solutions with crude oil while different stability emulsions are formed. The dynamic viscosity and phase separation ability of emulsions influence the flow rate in the pores of the reservoir rock. The measurement methods of emulsions completed with investigation of phase viscosity of settled emulsions by using a Brookfield rotational viscometer.

Keywords: EOR, crude oil - water emulsion, viscosity, Brookfield viscometer.

\section{Összefoglalás}

A polimer-tenzides harmadlagos kitermelés (EOR) során a vizes tenzidoldatok és a kőolaj keveredésekor különböző stabilitású emulziók alakulnak ki. Ezek tárolókőzet pórusain történő áramlási sebességét nagymértékben befolyásolja a dinamikai viszkozitásuk és fázisszétválasztással szembeni stabilitásuk. A kőolaj tenzides kiszorítási technológiájának kutatásához az emulziók vizsgálati módszerét az ülepített emulziók fázisviszkozitásainak mérésével egészítettük ki, Brookfieldtípusú rotációs viszkoziméter alkalmazásával.
\end{abstract}

Kulcsszavak: EOR, köolaj-viz emulzió, viszkozitás, Brookfield viszkoziméter.

\section{Bevezetés}

Az elsődleges és másodlagos kőolaj kitermelési módszerekkel a kőolajtárolók olajtartalmának csupán 50-60\%-a hozható a felszínre [1]. A kitermelési hatásfok további növelése érdekében fejlesztették ki a kémiai kiszorításon alapuló harmadlagos eljárást (EOR). Kutatómunkánk során a kémiai, azon belül is a polimer-tenzides harmadlagos kőolaj-kitermeléssel foglalkoztunk. Ezen eljárásnál a vizes tenzidoldatok és a kőolaj keveredésekor különböző stabilitású 
emulziók alakulnak ki, amelyek reológiai tulajdonságai nagymértékben befolyásolják a kőolaj kitermelés hatékonyságát $[2,3]$.

Vizsgálataink célja volt, hogy az EOR célra előállított tenzidkompozíció felhasználásával készített és ülepedő kőolaj-víz emulziót reológiai szempontból jellemezni tudjuk az ülepedő emulzió folyadékoszlop magasságának függvényében.

\section{Felhasznált anyagok}

\subsection{Alkalmazott kőolaj}

A vizsgálatok során az 1. táblázatban feltüntetett tulajdonságú algyői kőolajat használtunk fel.

1. táblázat. Felhasznált kőolaj jellemzői

\begin{tabular}{|l|c|}
\hline \multicolumn{1}{|c|}{ Jellemzö } & Érték \\
\hline Sürüség, g/cm ${ }^{3}\left(20^{\circ} \mathrm{C}\right)$ & 0,847 \\
\hline $\begin{array}{l}\text { Dinamikai viszkozitás, } \\
\text { mPas }\left(50^{\circ} \mathrm{C}\right)\end{array}$ & 12,87 \\
\hline Dermedéspont, ${ }^{\circ} \mathrm{C}$ & 22 \\
\hline $\begin{array}{l}\text { Watson-féle } \\
\text { karakterizáló tényező }\end{array}$ & 13,2 \\
\hline Karakter & Paraffinos \\
\hline
\end{tabular}

\subsection{Alkalmazott rétegvíz}

A vizsgálatokat algyői rétegvízzel végeztük, amely föbb paramétereit a $\mathbf{2}$. táblázat tartalmazza.

2. táblázat. Felhasznált rétegviz paraméterei

\begin{tabular}{|l|c|}
\hline \multicolumn{1}{|c|}{ Paraméter } & Érték \\
\hline $\begin{array}{l}\text { Eleketromos vezetőképesség } \\
\left(20^{\circ} \mathrm{C}\right), \mathrm{mS} / \mathrm{cm}\end{array}$ & 3,38 \\
\hline pH-érték & 8,4 \\
\hline $\begin{array}{l}\text { TDS (összes oldott anyag) } \\
\left(105^{\circ} \mathrm{C}\right), \mathrm{mg} / \mathrm{l}\end{array}$ & 3860 \\
\hline
\end{tabular}

\subsection{Vizsgált tenzidkompozíciók}

Méréseinkhez saját fejlesztésű anionos és nemionos tenzideket használtunk fel. A tenzidkompozíciókból (3. táblázat) adott koncentrációjú oldatokat készítettünk, majd ezekhez folyásmódosító polimer adtunk. Ezt követően tanulmányoztuk a különbözö emulgeátorok hatását az emulzió képződésre.

3. táblázat. Felhasznált tenzidkompozició összetétele

\begin{tabular}{|c|c|c|}
\hline $\begin{array}{c}\text { Tenzid- } \\
\text { kompozíció } \\
\text { jele }\end{array}$ & $\begin{array}{c}\text { Anionos } \\
\text { tenzid }\end{array}$ & $\begin{array}{c}\text { Nemionos } \\
\text { tenzid }\end{array}$ \\
\hline $\mathrm{K}-1$ & $\mathrm{~A}-170 \%$ & $\mathrm{~N}-130 \%$ \\
\hline $\mathrm{K}-2$ & $\mathrm{~A}-170 \%$ & $\mathrm{~N}-230 \%$ \\
\hline $\mathrm{K}-3$ & $\mathrm{~A}-270 \%$ & $\mathrm{~N}-130 \%$ \\
\hline
\end{tabular}

\section{Mérőmű́szer}

A mérésekhez Brookfield DV-III digitális programozható rotációs reoviszkozimétert alkalmaztunk.

\section{Mérési módszer}

A kőolaj-víz emulziók készítése során $50 \quad \mathrm{~cm}^{3} \quad$ össztérfogatban $\quad 1,5 \quad \%$-os emulgeátor elegyet tartalmazó rétegvizes oldatot készítettünk majd azt $50 \mathrm{~cm}^{3}$ kőolajjal elegyítve, intenzív rázással homogenizáltuk.

$\mathrm{Az}$ ülepedés révén szétváló fázisok viszkozitásának méréséhez az emulziót duplafalú termosztálható edénybe öntöttük, majd azonnal megmértük az emulzió viszkozitását a folyadékoszlop magasságának függvényében. Ezt követően $80^{\circ} \mathrm{C}$-on 2 órán keresztül nyugalmi állapotban termosztálást végeztünk, majd megismételtük a viszkozitás mérést. Eközben feljegyeztük a vizuálisan meghatározott fázishatárokat.

\section{Mérési eredmények}

A mérési eredményeket a 1-6. ábrákon mutatjuk be. A folyadékoszlop magasságában 18 mérési ponton mértük meg a dinamikai viszkozitást. A diagramokon a piros és a kék szaggatott vonalak a vizuálisan meghatározott 
olajfázis és az emulzió, valamint az emulzió és a víz közötti fázishatárokat jelölik.

\subsection{K-1 jelú tenzidkompozíció vizsgá- lata}

A vizsgálat kezdetén a minta teljes térfogata emulziós fázisban volt. Viszkozitása a folyadékoszlop teljes magasságában 25 mPas nagyságú (1. ábra).

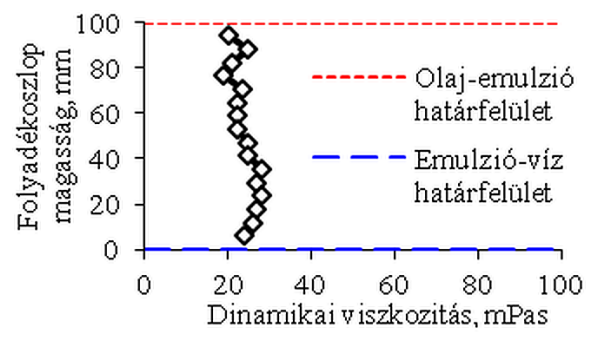

1. ábra. K-1 jelü tenzidkompozícióval készült köolaj-víz emulzió viszkozitása a magasság függvényében 0. perc

A mérés 30. percében már három fázis alakult ki: felül olajos, középen emulziós és alul vizes. A vizsgálat 120 perces intervalluma alatt a vizes fázis térfogata fokozatosan növekedett. 2 órás ülepedési időt követően az olajos fázis nagysága 5 $\mathrm{V} / \mathrm{V} \%$, a vizes fázis nagysága $30 \mathrm{~V} / \mathrm{V} \%$ volt (2. ábra).

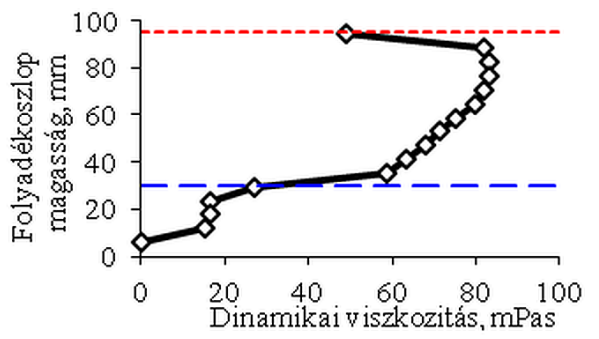

2. ábra. K-1 jelü tenzidkompozícióval készült köolaj-víz emulzió viszkozitása a magasság függvényében 120. perc

A fázisok kialakulása a viszkozitás értékek változásán is megmutatkozott. Az emulziós fázisban a viszkozitás értékek közel 80 mPas-ra emelkedtek. A vizuálisan meghatározott fázishatároknál a viszkozitás értékek meredeken megváltoztak, és alulról felfelé haladva az emulzió $\mathrm{O} / \mathrm{V}$ típusúról $\mathrm{V} / \mathrm{O}$ típusúra változott, továbbá fázisinverzió is megfigyelhető volt.

\subsection{K-2 jelű tenzidkompozíció vizsgá- lata}

A K-2 jelü tenzidkompozíció vizsgálatakor a kezdeti homogén emulziós fázis viszkozitása 10-30 mPas nagyságú (3. ábra).

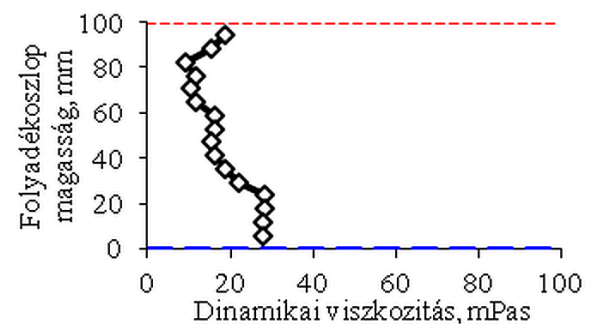

3. ábra. $K-2$ jelü tenzidkompozicióval készült köolaj-viz emulzió viszkozitása a magasság függvényében 0. perc

120 perces ülepedést követően a felsö, olajos fázis mennyisége $20 \mathrm{~V} / \mathrm{V} \%$ volt, az emulziós fázis nagysága $40 \quad \mathrm{~V} / \mathrm{V} \%$-ra csökkent (4. ábra).

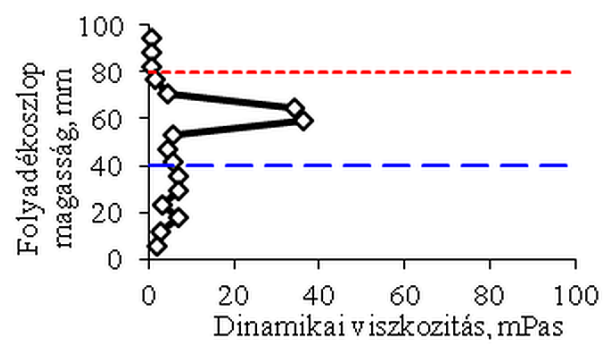

4. ábra. $K-2$ jelü tenzidkompozicióval készült köolaj-víz emulzió viszkozitása a magasság függvényében 120. perc

A viszkozitás értékek a vizes és az olajos fázisban 10 illetve $5 \mathrm{mPas}$ alattiak. A vizsuálisan megfigyelt fázishatárnál a viszkozitás értékeknél jelentős változást nem tapasztalunk, azonban az emulzió 
fázisinverziójának tartományában közel 40 mPas-os viszkozitás növekedést mértünk.

\subsection{K-3 jelú tenzidkompozíció vizsgá- lata}

A K-3 jelü tenzidkompozícióból előállított emulzió kezdetben homogén, relatíve nagy (55 mPas) dinamikai viszkozitású fázist alkotott (5. ábra).

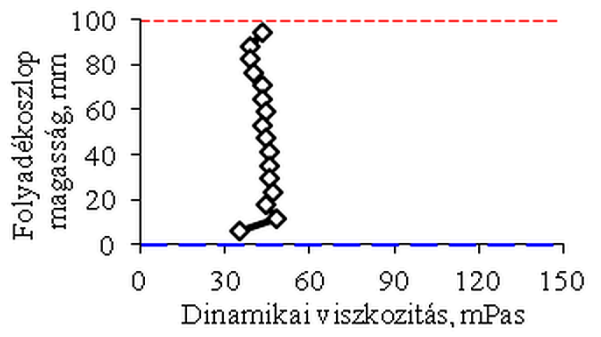

5. ábra. $K$-3 jelü tenzidkompozicióval készült köolaj-viz emulzió viszkozitása a magasság függvényében 0. perc

A vizsgálat 120. percében a felső, olajos fázis nagysága csupán $3 \mathrm{~V} / \mathrm{V} \%$ volt, az alsó vizes fázis aránya $40 \mathrm{~V} / \mathrm{V} \%$ lett (6. ábra).

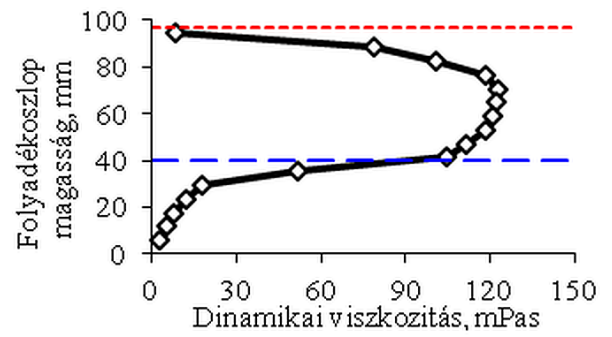

6. ábra. $K$-3 jelü tenzidkompozicióval készült köolaj-viz emulzió viszkozitása a magasság függvényében 120. perc

A viszkozitás értékek változásával ez esetben is nyomonkövethetö a fázisváltozás. A vizuálisan meghatározott víz-olaj emulzió határfelületnél a viszkozitás értékeknél jelentős, közel 100 mPas, emelkedést tapasztaltunk. A V/O típusú emulziós fázisban ezek az értékek tovább nüvekedtek, kb. 130 mPas-ig. Az olaj-emulzió határfelületnél szintén fázisinverziót és átmeneti fázist feltételeztünk, mivel a viszkozitás abban az esetben is jelentősen megváltozott. A folyadékoszlop $60 \%$-át követően az olajban emulgeált víz koncentrációjának fokozatos csökkenésével párhuzamosan a viszkozitás is egyre jobban megközelítette a kőolaj 5 mPas körüli viszkozitását.

\section{Következtetések}

A kőolaj tenzides kiszorítási technológiájának kutatásához az emulziók vizsgálati módszerét az ülepített emulziók fázisviszkozitásainak mérésével egészítettük ki.

A vizsgált emulziók esetén megállapítottuk, hogy a tenzidkompozíció anionos és nemionos tenzid alkotója befolyásolja a kialakult emulzió típusát és mennyiségét. A vizuálisan meghatározott és a valós fázishatár nem minden esetben egyezik.

A bemutatott módszert alkalmasnak találtuk a valódi fázishatárok és átmeneti fázisok megállapítására. Kimutattuk, hogy az így kidolgozott módszer alkalmas a tenzidek összetétel-változásának, az emulziókészítési illetve tárolási paraméterek hatásainak értékelésére és relatív összehasonlítására.

\section{Szakirodalmi hivatkozások}

[1] Pápay J.: Szénhidrogéntelepek müvelési technológiájának szinergiája, Köolaj és Földgáz, 2005/3, 1-8.

[2] William C. Lyons: Standard Handbook of Petroleum and Natural Gas Engineering: Volume 2, Gulf Professional Publishing, 1996., 319-343

[3] Abass A. Olajire: Review of ASP EOR (alkaline surfactant polymer enhanced oil recovery) technology in the petroleum industry: Prospects and challenges, Energy 77, 2014., 963-982 